\title{
Introspection into Indian School Education System
}

\begin{abstract}
This article probes deeper into the Indian school education system and states that there is a deep rooted systemic flaws in the pedagogical planning and execution. It reviews and discuss on policy and regulatory changes or reforms needed in the existing system. An attempt is made to analyze our school education system and identify its challenges and thereby put forward possible building blocks for reviving our education system.
\end{abstract}

Abshana Jamal
Keywords: School education, Pedagogy, Challenges, Prospects.

\section{INTRODUCTION}

"Education is the most powerful weapon which you can use to change the world."

\section{Nelson Mandela}

It is no secret that a good education has the power to change a life. What is new is the demand for that change. Governments are investing more than ever before on educating their citizens, eager for them to compete in the global workforce. While we all understand how crucial education is to shape our lives, it has also been a major problem in our country. There are several issues that the Indian education system is grappled with. We cannot deny the fact that the Indian government and institutions have been working to reform the existing education model. However, there are still several issues which are required to be taken care of.

The fundamental source of tension in the design of an education system comes from the fact that, historically, education system have served two different purposes. First, they have sought to impart knowledge, skills and shared concepts of identity and citizenships. We can broadly refer to these as the 'human development' role of education. However, education system have also served a second purpose, which is to assess and classify students on the basis of educational ability and achievement and to select higher achieving students for higher education and occupations that aim to attract the most meritorious students. This can be referred as 'sorting' function of education. (Muraleedharan, 2019).

A quick glimpse of our education system after Independence would suggest that the education system is mostly driven by the sorting function rather the human development. Indeed, the Indian education system in its

Revised Manuscript Received on March 13, 2020.

* Correspondence Author

Abshana Jamal*, Dept. of Social Work, Rajagiri College of Social Sciences, Kalamassery, Kerala India. Email: abshanasaraf@gmail.com

(C) The Authors. Published by Blue Eyes Intelligence Engineering and Sciences Publication (BEIESP). This is an open access article under the CC BY-NC-ND license (http://creativecommons.org/licenses/by-nc-nd/4.0/) current form is perhaps best understood as a 'filtration system' rather than an 'education system'. The structural challenges with our system of education system can be solved by using this framework as reference.

\section{KEY CHALLENGES}

\section{Massive inequalities}

There exist a massive inequality between the students who complete their schooling in India. On one hand we produce students who are extremely meritorious to go on to achieve global excellence in their field, whereas on the other hand produces world's largest number of primary-school students who are not functionally literate and numerate at even a second or third grade level.

\section{Rote learning}

We concentrate more on exams and marks, which has led to an education system characterized by rote learning to pass the exams, which is the pole opposite to the conceptual understanding that can be applied and used in practical situations. An emphasis on 'passing exams' has meant that students focus on memorization rather than on picking up useful skills and concepts. Vocational training is not considered important.

\section{Unequal respect for subjects}

We continue to survive in the education system where science stream topples the stream hierarchy. Students are pushed to become a machine which only goes for high-profile subjects and subjects like languages, communications, and arts are looked down and are not considered high-profile. Students should rather be pushed to pursue the subject that they like instead of creating a differentiation between subjects (India today webdesk, 2019)

\section{Unskilled teachers}

Teachers play the most important role in schools and hence, they should be given the best of class training. With the constantly changing syllabus and curriculum, teachers themselves feel stressed and unskilled to meet the growing educational expectation. When they are knackered, this will be directly or indirectly taken over to the students, resulting in a dissident relation with the teachers.

\section{Unmindful purpose}

We are still stuck up with what the colonial educators have taught us. We often talk of education as being an instrument of economic development of self and society. Sometimes, we also allude to it as being an instrument to help one prepare for critical, democratic citizenship. 
But rarely do we talk of education being a process to help a person form his authentic self. It is high that we as a country, start taking education above the mediocre level that we have been engrained with and perceive education from the holistic approach (Dhankar, 2015). Very low levels of practical skills even among students who have notionally 'passed' various exams and possess various levels of paper qualifications.

Education has been reduced to the level of 'teaching for testing'. The individual is completely lost. All that is visible are aggregates of a tiny part of the human capability, measured through tools of suspicious reliability (Dhankar, 2015). The central design challenge for the Indian education system is that it was designed for sorting and not for human development. Almost every structural aspect of Indian education system can be explained by this framework. Thus the fundamental goal for Indian education policy has to be to move the education system from a sorting and selection paradigm to a human development paradigm, one that will empower every citizen to be educated enough to have the foundation needed for a lifetime of continuous learning in whichever area of skill he or she may seek to learn.

\section{CORE BUILDING BLOCKS}

\section{Curriculum reform to reduce content and emphasize understanding}

The current curriculum has way too much content, which in turn pushes the education system to deliver rote learning as opposed to the conceptual understanding. There is already a lot of good content and ideas in the Yash Pal Committee on the National Curriculum Framework 2005. Learning without burden, is one of the main focus of NCF, to make learning a joyful experience and move away from textbooks to be a basis for examination and to remove stress from children (K.M. , 2005). But that has not been acted on. A content heavy approach is again rampant with the sorting system since the sheer volume of material to be covered makes it more likely that students with better academic aptitude will score better in exams.

Thus, we should focus on narrowing and simplifying the volume of contents to be covered and instead prioritize on cultivating the ability to understand concepts, linking the concepts across domains, and apply them creatively to find solutions for the existing and newer problems.

Thus reorienting the education system towards the human development paradigm, as opposed to the sorting function, will require a fundamental restructuring in the examination system, which is also oriented towards the sorting function.

\section{Reform of teacher training to emphasize pedagogy over theory}

The teacher is the single most important determinant of the quality of education received by the students, and it is hoped that having qualified teachers will help to improve the quality of education. The corner stone of RTE is a requirement that all teachers possess a formal teacher training credential. Unfortunately, this requirement is not supported by evidence. Multiple studies have shown that there is no correlation between a teacher possessing a formal teacher training credential and his or her effectiveness in the classroom as measured by the improvements in learning outcomes during the period that the students are with that teacher (Kingdon \& Teal, 2010; Muralidharan \& Sundararaman, 2011; Muralidharan, 2012).

Of course, this doesn't imply that teacher training cannot be effective. However, the evidence shows that that status quo of teacher training is broken and ineffective. This point is made clear in Justice Verma Commission Report of 2012).

There is a great need for professional standards and regulation of pre-service teacher training institutes, $90 \%$ of which are in the private sector and are largely sub-standard and unregulated. Even the state-run institutes suffer from multiple deficiencies and most of them are far from being effective. Thus, developing institutional mechanisms for periodic monitoring of teacher training institutes and strict adherence to quality parameters is vital. Additionally, clear selection criteria for testing aptitude needs to be in place before accepting students into teacher training colleges (Vakil, 2016). Improving the quality of in-service training, focusing on, effective pedagogy and a regulatory mechanism to assess the teacher on their comprehension of the training module.

\section{Vocational education streams}

Indian job crisis in merely the skill crisis with million 'educated' unemployed youth on one hand and the employers constantly complaining that they cannot find the right skilled candidate for the vacant positions. A major reason for this is the focus of our current education system on passing the exams with no real understanding of the subject matter. Vocational education is seen as something that is chosen by those who are academically weaker. Singapore, Germany and Switzerland, which can be considered as leading education system in the world, features tracking of students into vocational education after sixth grade. By adopting these kind of approach, would serve millions of students who thrive to pass the exams but unable to find the job.

\section{CONCLUSION}

Even having abundance of human resources, India is not able achieve the economic development that we are envisioning from the past decades. Quality of education is playing a critical role in this. Without making our younger minds to think critically, we won't be able to achieve the growth, both in social and economic terms. By solving the key problems and following the solutions such as innovative and new curriculum, reforming teacher training and adding vocational training, we will be able to achieve a quality education.

\section{REFERENCES}

1. Dhankar, R. (2015, May 05). Another brick in the wall.... The Hindu. Retrieved from https://www.thehindu.com/opinion/lead/educational-development-ano ther-brick-in-the-wall/article7170961.ece

2. FICCI, Ernst, \& Young. (2014). Private sector's Contribution to K-12 Education in India: Current Impact, Challenges and Way Forward.

3. India today webdesk. (2019, $08 \quad 09)$. 7-immediate-changes-needed-in-the-indian-education-system. India Today.

4. Muralidharan, K. (2012). Long Term Effects of Teacher Performance Pay: Experimental Evidence from India.

5. K.M. , S. (2005). Another retreat of reason. Frontline.

6. Kingdon, G., \& Teal, F. (2010). Teacher Unions, Teacher Pay and Student Performance in India: A Pupil Fixed Effects Approach. Journal of Development Economics, 91: 278-88. 
7. Muraleedharan, K. (2019). Reforming the Indian School education system. In A. Banerjee, G. Gopinath, R. Rajan, \& M. s. Sharma, What the economy needs now (pp. 129-166). New Delhi: Juggernaut books.

8. Muralidharan, K., \& Sundararaman, V. (2011). Teacher performance pay: experimental Evidence from India. Jounal of Political economy, 119: 39-77.

9. Vakil, S. (2016, September 5). Teaching teachers, the great challenge for India's education system. Hindustan Times.

10. (n.d.)

Retrieved from https://www.pearson.com/news-and-research/efficacy/importance-ofeducation.html (n.d.). Retrieved from https://mhrd.gov.in/nep-new

\section{AUTHORS PROFILE}

\begin{tabular}{|c|c|c|}
\hline & \multicolumn{2}{|c|}{$\begin{array}{l}\text { Ms. Abshana Jamal, } \\
\text { Mail id: abshanasaraf@gmail.com }\end{array}$} \\
\hline Academics Course & 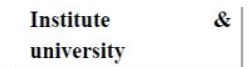 & Year of passing \\
\hline MSW & $\begin{array}{l}\text { Rajagiri College of } \\
\text { Social Sciences } \\
\text { Kalamassery }\end{array}$ & 2018 \\
\hline $\begin{array}{l}\text { PG Diploma in } \\
\text { Youth Development }\end{array}$ & $\begin{array}{l}\text { Rajiv Gandhi National } \\
\text { Institute of Youth } \\
\text { Development Chennai }\end{array}$ & 2017 \\
\hline B.A History & $\begin{array}{l}\text { All Saints' College } \\
\text { Trivandrum }\end{array}$ & 2016 \\
\hline $\begin{array}{l}\text { Class } 12 \\
\text { (comp- maths) }\end{array}$ & 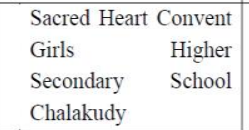 & 2012 \\
\hline Class 10 & $\begin{array}{l}\text { Presentation } \\
\text { Girls Highrent } \\
\text { Vellikulangara }\end{array}$ & 2010 \\
\hline
\end{tabular}

Professional career summary:

- Working as Assistant professor in Social work, Rajagiri College of Social

Sciences, Kalamassery, Kerala

- Worked as Assistant professor in Social work, St. Joseph's College,

Irinjalakuda 